\title{
Hydrochemical Characteristics of Springs in Oke-Igbo, Ondo State, Nigeria
}

\author{
${ }^{1}$ AWOMESO, J A; ${ }^{2}$ GBADEBO, AM; $*{ }^{2}$ TAIWO, A M; ${ }^{1}$ OBAYOMI, O \\ ${ }^{I}$ Department of Water Resources Management and Agrometeorology. ${ }^{2}$ Department of Environmental Management and \\ ToxicologyUniversity of Agriculture, PMB 2240, Abeokuta Nigeria*Email: taiwoademat2003@yahoo.com
}

\begin{abstract}
This study was carried out to determine the hydrochemical characteristics of six springs in OkeIgbo community, Ondo state, Nigeria. Water samples were collected from the upper, middle and lower course of each spring and analyzed for temperature, $\mathrm{pH}$, electrical conductivity (EC), total dissolved solids (TDS), total alkalinity, total hardness, sodium $(\mathrm{Na})$, potassium $(\mathrm{K})$, calcium $(\mathrm{Ca})$, magnesium $(\mathrm{Mg})$, sulphate $\left(\mathrm{SO}_{4}{ }^{2-}\right)$, bicarbonate $\left(\mathrm{HCO}_{3}{ }^{-}\right)$, chloride $\left(\mathrm{Cl}^{-}\right)$, nitrate $\left(\mathrm{NO}_{3}{ }^{-}\right)$, bacteria count and Escherichia coli. Data collected were presented in simple descriptive statistics and tables. Results showed that most of the measured parameters fell within the maximum acceptable standards set by World Health Organization (WHO) with the exception of microbiological parameter in which high coliform colonies were observed at the lower courses of each spring. The $\mathrm{pH}$ of the springs was generally low ranging from slightly acidic to acidic. The presence of bacteria count and Escherichia coli in the springs' water indicated fecal pollution, which could result in related water-borne diseases. Boiling of the spring water, is therefore, recommended before consumption.
\end{abstract}

Oke-Igbo Community, in Ondo State, Southwest Nigeria is blessed with many springs that are spread across the town. The springs are the main sources of domestic water supply for the entire community. Access to clean water and basic sanitation has become the theme of various health-related organizations in the world. It is therefore, of paramount importance for a thorough analysis of all water sources to be carried out, since the provision of piped borne water for rural communities in Nigeria is far from being implemented. Lamoreaux and Tanner (2001) have described spring as a location where groundwater naturally emerges from the earths subsurface in a defined flow and in amount to form a pool or stream-like flow. Freshwater from the spring could be directly discharged onto the ground surface, directly into the beds of rivers or streams or into the ocean below sea level (Lamoreaux and Tanner, 2001). Spring water is associated in the public mind with exceptional quality. As a matter of fact, bottling of spring water has become a blooming business across the world (King, 2008). The importance of springs have gone beyond just being sources of domestic and municipal water supply but also sources for foreign exchange earning as they serve as places for tourist attraction (Aniah, et al., 2009) and industrial establishment where safe drinking water could be bottled. However, the water bearing strata of the spring called aquifers could contain unconsolidated materials like sand, gravels, glacial drift or consolidated materials like sandstones and limestone that could affect the hydrochemistry of the spring water. Treatment of spring's water is therefore necessary to guide against outbreak of water borne diseases. This research work is therefore, focused on the determination of the hydrochemical parameters of springs in Oke-Igbo community with the aim of establishing their potability.

The study Area: Oke-Igbo Community is situated in the western part of Ondo State, sharing boundaries in the East with Ondo and Ifedore Local Government Areas of Ondo State and in the west by Osun State. The community lies between longitude $4^{\circ} 11^{\prime} \mathrm{E}$ and latitude $7^{\circ} 10^{\prime} \mathrm{N}$. It is a heterogeneous community, consisting of various groups of people from the entire Yoruba speaking towns. The six (6) studied springs are shown in Figure 1. The regional geology of Ondo state in which the study area is a part consists of the two major rock types viz: the basement complex rocks of Precambrian age and the sedimentary rocks of Cretaceous to Recent Age. Oke Igbo, the study area belongs to the basement rocks of the state which according to Odigi et al. (1993) consists of Migmatite gneiss complex, metasediments and older granites. The study area is also very rich in quartzites which form ridges and have undergone series of tectonic activities. The quartzites, which are in block forms, are exposed in most of the locations due to weathering and erosion. This probably serves as sources of the springs in the community.

Reconnaissance survey: An intensive survey of the study area was carried out prior to commencement of the research so that one will be acquainted with the entire terrain. The 6 springs chosen were georeferenced, and information on their latitudinal, longitudinal locations and their reference elevation above sea level were documented. The discharge or flow and various uses of the springs were also highlighted as presented by the residents (Table 1). 


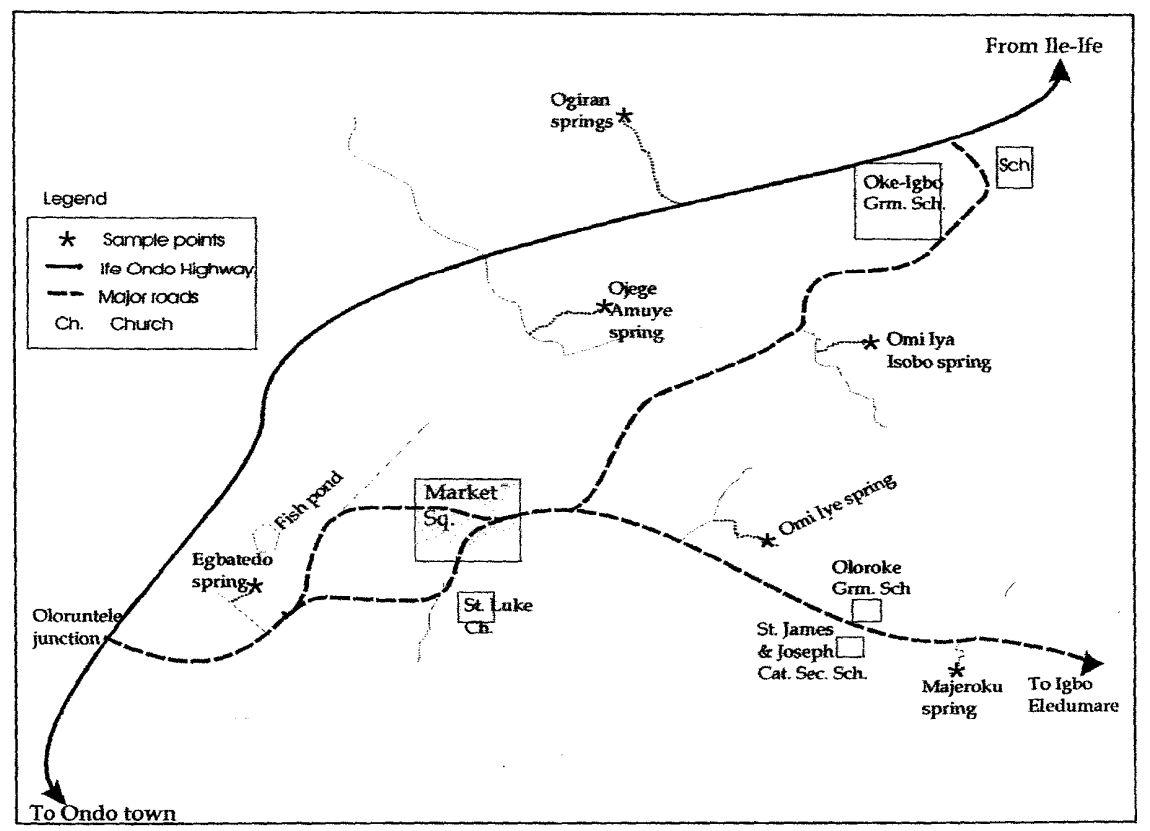

Fig 1: Map of Oke Igbo commnuity showing the six springs

Table 1: Result of Reconnaissance Survey

\begin{tabular}{|c|c|c|c|c|l|}
\hline Springs & $\begin{array}{c}\text { Longitude } \\
(\mathrm{E})\end{array}$ & $\begin{array}{c}\text { Latitude } \\
(\mathrm{N})\end{array}$ & $\begin{array}{c}\text { Elevation } \\
(\mathrm{m})\end{array}$ & $\begin{array}{c}\text { Discharge } \\
(\mathrm{L} / \mathrm{s})\end{array}$ & \multicolumn{1}{c|}{ Observed Uses } \\
\hline Majeroku & $4^{\circ} 43^{\prime} 42^{\prime \prime}$ & $7^{\circ} 11^{\prime} 22^{\prime \prime}$ & 245 & 0.24 & Washing of cars, bikes, bathing and drinking. \\
\hline Omi Iye & $4^{\circ} 43^{\prime} 25^{\prime \prime}$ & $7^{\circ} 10^{\prime} 33^{\prime \prime}$ & 215 & 0.20 & Washing of clothes, drinking \\
\hline Omi Iya Isobo & $4^{\circ} 43^{\prime} 15^{\prime \prime}$ & $7^{\circ} 10^{\prime} 30^{\prime \prime}$ & 199 & 0.30 & $\begin{array}{l}\text { Washing of clothes, bathing, and washing of farm } \\
\text { implements }\end{array}$ \\
\hline Ogiran & $4^{\circ} 43^{\prime} 15^{\prime \prime}$ & $7^{\circ} 9^{\prime} 48^{\prime \prime}$ & 221 & 0.03 & Washing, bathing and drinking. \\
\hline Ojege Amuye & $4^{\circ} 43^{\prime} 30^{\prime \prime}$ & $7^{\circ} 9^{\prime} 33^{\prime \prime}$ & 228 & 0.14 & Strictly for drinking and domestic purposes \\
\hline Egbatedo & $4^{\circ} 44^{\prime} 10^{\prime \prime}$ & $7^{\circ} 9^{\prime} 39^{\prime \prime}$ & 225 & 0.24 & Drinking and domestic purposes \\
\hline
\end{tabular}

\section{MATERIALS AND METHODS}

A total of six (6) springs: Majeroku, Omi Iye, Omi Iya Isobo, Ogiran, Ojege Amuye and Egbatedo were sampled and water collected with the aid of prewashed white plastic kegs (2L). Samples for metals assay were collected with pre-washed $1 \mathrm{~L}$ kegs and fixed immediately with $2 \mathrm{~mL}$ concentrated nitric acid and samples for anions determination were analyzed within seven days of collection. Water samples for microbiological parameters were collected separately with sterile McCartney bottles and analysis carried out within 24 hours. Samples were collected from each spring at upper, middle and lower courses.

Water samples were analyzed using standard procedures (APHA, 1989). The parameters determined were: temperature, $\mathrm{pH}$, electrical conductivity (EC), total dissolved solids, total alkalinity, total hardness, sodium $(\mathrm{Na})$, potassium $(\mathrm{K})$, calcium $(\mathrm{Ca})$, magnesium $(\mathrm{Mg})$, sulphate $\left(\mathrm{SO}_{4}{ }^{2-}\right)$, bicarbonate $\left(\mathrm{HCO}_{3}{ }^{-}\right)$, chloride $\left(\mathrm{Cl}^{-}\right)$, nitrate $\left(\mathrm{NO}_{3}{ }^{-}\right)$, bacteria count and Escherichia coli (E. coli). Temperature was measured in-situ using mercury in glass thermometer; turbidity, $\mathrm{pH}, \mathrm{EC}$ and TDS were measured in-situ electronically with combined pH/EC/TDS meter (Combo HI 98130, Hanna, USA).
Nitrate was also determined by salycyclate colorimetric method, hardness chloride, bicarbonate, sulphate and alkalinity were analyzed by titrimetric method. Calcium (Ca) and magnesium $(\mathrm{Mg})$ were determined by atomic absorption spectrophotometry (AAS) (Buck, 200 model), sodium (Na) and potassium $(\mathrm{K})$ were determined by flame photometry (Model PFP 7, Jenway, UK) after the samples were digested with $10 \mathrm{~mL}$ concentrated hydrochloric acid on an electric hotplate for 30 minutes. Microbial analysis was carried out by plate count method.

\section{RESULTS AND DISCUSSIONS}

Results of the springs hydrochemical and microbiological parameters were shown in Table 2-4 respectively. The results ranged as follows: temperature $\left(24-27^{\circ} \mathrm{C}\right), \mathrm{pH}(4.8-6.8)$, electrical conductivity $(30-90 \mu \mathrm{S} / \mathrm{cm})$, total dissolved solids $(10-40 \mathrm{mg} / \mathrm{L})$, total alkalinity $(2.0-8.0 \mathrm{mg} / \mathrm{L})$, total hardness $(5.0-23.0 \mathrm{mg} / \mathrm{L})$, sodium $(2.0-6.0 \mathrm{mg} / \mathrm{L})$, potassium $(1.0-3.0 \mathrm{mg} / \mathrm{L})$, calcium $(0.99-2.84$ $\mathrm{mg} / \mathrm{L})$, magnesium $(1.34$ - $3.65 \mathrm{mg} / \mathrm{L})$, sulphate $(21.38$ - $92.30 \mathrm{mg} / \mathrm{L})$, bicarbonate $(24.40-73.20$ $\mathrm{mg} / \mathrm{L})$, chloride $(15.0-18.50 \mathrm{mg} / \mathrm{L})$, nitrate $(0.35-$ $5.06 \mathrm{mg} / \mathrm{L})$, bacteria count $(5 \mathrm{col} / 100 \mathrm{~mL}$ - TNTC) and Escherichia coli $(0-160 \mathrm{col} / 100 \mathrm{~mL})$. 
Vol. 14 (3) $41-45$

Table 2: Result of some Physico-chemical Parameters of the spring water samples

\begin{tabular}{|c|c|c|c|c|c|c|c|c|}
\hline Springs & Course & $\begin{array}{l}\text { Temp. } \\
\left({ }^{\circ} \mathrm{C}\right)\end{array}$ & $\mathrm{pH}$ & $\begin{array}{c}\mathrm{EC} \\
(\mu \mathrm{S} / \mathrm{cm})\end{array}$ & $\begin{array}{c}\text { TDS } \\
(\mathrm{mg} / \mathrm{L})\end{array}$ & $\begin{array}{l}\text { Turbidity } \\
\text { ( mg/L) }\end{array}$ & $\begin{array}{c}\text { Total alkalinity } \\
\text { ( } \mathrm{mg} / \mathrm{L})\end{array}$ & $\begin{array}{c}\text { Total hardness } \\
(\mathrm{mg} / \mathrm{L})\end{array}$ \\
\hline \multirow[t]{2}{*}{ Majeroku } & Upper & 24 & 6.5 & 50 & 20 & 16.41 & 4.0 & 12.0 \\
\hline & Middle & 24 & 6.6 & 60 & 20 & 16.59 & 4.0 & 12.0 \\
\hline \multirow[t]{3}{*}{ Omi Iye } & Upper & 26 & 5.7 & 60 & 30 & 6.52 & 2.0 & 10.0 \\
\hline & Middle & 26 & 5.3 & 60 & 30 & 7.82 & 2.0 & 11.0 \\
\hline & Lower & 26 & 5.1 & 60 & 30 & 7.22 & 8.0 & 11.0 \\
\hline \multirow{2}{*}{ Omi Iya Isobo } & Middle & 25 & 6.2 & 50 & 20 & 6.76 & 4.0 & 7.0 \\
\hline & Lower & 25 & 6.1 & 50 & 20 & 13.31 & 4.0 & 9.0 \\
\hline \multirow[t]{3}{*}{ Ogiran } & Upper & 26 & 6.2 & 80 & 30 & 15.34 & 4.0 & 23.0 \\
\hline & Middle & 25 & 6.1 & 70 & 30 & 17.83 & 2.0 & 22.0 \\
\hline & Lower & 25 & 6.2 & 70 & 20 & 19.43 & 4.0 & 12.0 \\
\hline Ojege Amuye & Upper & 26 & 5.8 & 90 & 40 & 5.04 & 4.0 & 12.0 \\
\hline Egbatedo & Lower & 25 & 5.0 & 30 & 10 & 13.74 & 6.0 & 10.0 \\
\hline
\end{tabular}

Spring's temperature was optimal and suitable for drinking purposes. There is no WHO standard for temperature. However, CEC (1998) recommended an optimal temperature standard of $25^{\circ} \mathrm{C}$ in drinking water. High water temperature could result into thermal pollution with subsequent effect on aquatic organisms. Spring water $\mathrm{pH}$ was generally low ranging from slightly acid in Majeroku, Omi Iya Isobo and Ogiran springs to acidic in Omi Iye, Ojege Amuye and Egbatedo springs. With the exception of Majeroku spring, the $\mathrm{pH}$ of other springs fell within WHO standard in drinking water of range 6.5-8.5.
Low $\mathrm{pH}$ of the spring might be attributed to dissolution of carbonic acid from weathering process of the parent rocks, which the springs flow through (Zhou, 2006). Metals tend to dissolve more in low water $\mathrm{pH}$. This could have health implication when deleterious heavy metals like lead and cadmium are washed into the spring via runoff. Low values of alkalinity, which ought to have served as buffer to the spring against sudden change in $\mathrm{pH}$ might also responsible for generally low $\mathrm{pH}$ especially during acid precipitation.

Table 3: Results of Cations and Anions of the analysed spring samples



Conductivity values were generally low when compared with acceptable limits for $\mathrm{EC}$ in natural water given by Mento (1980) as $400-1250 \mu \mathrm{S} / \mathrm{cm}$. TDS values for all the spring samples were less than $600 \mathrm{mg} / \mathrm{L}$ set by World Health Organization, WHO (2008) in drinking water. High EC and TDS values in water are indications of dissolved minerals in water. By and large, there are no health concerns for TDS and EC. TDS of the springs being less than 300 $\mathrm{mg} / \mathrm{L}$ could be rated excellent according to Bruvold and Ongerth (1969). Turbidity values of the springs were high in Majeroku, Ogiran and Egbatedo springs probably due to their relief. Water from the spring may carry particles and other substances as it flows from high altitude to low terrain. Effect of turbidity is reduced light penetration in the stream, water coloration and lowering of dissolved oxygen (Department of National Health and Welfare (Canada), 1978). Total alkalinity and hardness values were low and fell within the maximum limits of 500 $\mathrm{mg} / \mathrm{L}$ (EPA, 2006). Low alkalinity observed in these studied springs may be dangerous if there's runoff of acid-containing substances or acid precipitation. The 
Hydrochemical Characteristics of Springs.....

whole spring will turn acidic. Low water $\mathrm{pH}$ could lead to corrosion (Nordberg et al., 1985). Environment Canada (1977) has classified hardness in drinking water in terms of its calcium carbonate concentration as follows: soft $(0-60 \mathrm{mg} / \mathrm{L})$, medium hard $(60-120 \mathrm{mg} / \mathrm{L})$, hard $(120-180 \mathrm{mg} / \mathrm{L}$ and very hard $(180 \mathrm{mg} / \mathrm{L}$ and above). Oke Igbo springs fell under soft hardness. This might be reasons why people prefer the spring's water for washing purposes especially the Omi Iya Isobo spring with exceptional low hardness values.
Sodium values were very low relative to the maximum acceptable limits of $200 \mathrm{mg} / \mathrm{L}$ in drinking water (WHO, 2008). There are no health-based guidelines for $\mathrm{K}$ in drinking water (Nkono et al, 1998). As a matter of fact, both elements are essential for body proper functioning. Calcium and magnesium are also essential element needed by the body metabolism. There are no health-based guidelines for both metals in drinking water by WHO or any international body. However, for aesthetics, WHO (2008) has set a Ca range of $100-200 \mathrm{mg} / \mathrm{L}$ in drinking water.

Table 4: Result of bacteriological analysis of spring samples

\begin{tabular}{|c|c|c|c|c|}
\hline Springs & Course & $\begin{array}{l}\text { Bacteria count } \\
\text { (col/100 mL) }\end{array}$ & $\begin{array}{l}\text { Escherichia } \\
\text { (col/100ml) }\end{array}$ & coli \\
\hline \multirow[t]{3}{*}{ Majeroku } & Upper & TNTC & 0 & \\
\hline & Middle & TNTC & 0 & \\
\hline & Lower & TNTC & 160 & \\
\hline \multirow[t]{3}{*}{ Omi Iye } & Upper & TNTC & 20 & \\
\hline & Middle & TNTC & 160 & \\
\hline & Lower & TNTC & 160 & \\
\hline \multirow[t]{3}{*}{ Omi Iya Isobo } & Upper & TNTC & 0 & \\
\hline & Middle & TNTC & 160 & \\
\hline & Lower & TNTC & 160 & \\
\hline \multirow[t]{3}{*}{ Ogiran } & Upper & 5 & 160 & \\
\hline & Middle & 12 & 160 & \\
\hline & Lower & 22 & 50 & \\
\hline \multirow[t]{3}{*}{ Ojege Amuye } & Upper & TNTC & 0 & \\
\hline & Middle & TNTC & 50 & \\
\hline & Lower & TNTC & 160 & \\
\hline \multirow[t]{3}{*}{ Egbatedo } & Upper & TNTC & 20 & \\
\hline & Middle & TNTC & 50 & \\
\hline & Lower & TNTC & 160 & \\
\hline
\end{tabular}

TNTC- Too Numerous To Count

Anions values especially sulphate, bicarbonate and chloride were higher than cations values. All the anions values were with international standards. The results of sulphate and bicarbonate gave an impetus of the rock types of the aquifers the springs evolved from. The water type is $\mathrm{SO}_{4}{ }^{2-}$ and $\mathrm{HCO}_{3}{ }^{-}$types. Generally, the relative abundance series for the cations and anions at the source is $\mathrm{Na}^{+}>\mathrm{Mg}^{2+}>\mathrm{K}^{+}>$ $\mathrm{Ca}^{2+}$ and $\mathrm{SO}_{4}{ }^{2-}>\mathrm{HCO}_{3}{ }^{-}>\mathrm{Cl}^{-}>\mathrm{NO}_{3}{ }^{-}$. The water is safe for drinking in terms of the concentrations of anions and cations without any fear of health effect. The presence of high population of bacteria colonies in almost all the sampled springs except Ojege Amuye with low colonies is a cause of concern since the springs served as sources of drinking water for Oke-Igbo community. The presence of Escherichia coli in the springs especially at middle and lower course indicated fecal pollution (Edberg et al., 1988 and 1994). Majeroku, Omi Iya Isobo and Ojege Amuye springs at upper course recording zero value of E. coli indicated absence of runoff of fecal materials and organic wastes from nearby dumpsites (Taiwo, 2010). The altitude of the springs may have something to do with the zero value of $E$.coli at upper course while the presence of these microbes might be due to runoff of fecal matters from nearby bushes and dumping sites (Orebiyi et al., 2010). Both the bacteria count and $E$. coli are pathogenic organisms. Pathogens may pose a special health risk for infants, young children, and people with severely compromised immune systems (USEPA, 2002). Contact with pathogens during recreation can also result into other miscellaneous infections of the skin, eye, ear, nose, and throat (Stelma and McCabe, 1992).

Conclusion: Based on the hydrochemical and microbiological values obtained from the springs, the water could have been certified safe for consumption. Nevertheless, the presence of bacteria colonies and E.coli bacteria showed microbial contamination of the springs and hence, strongly advised against direct consumption by the people without prior treatment. For this could lead to incidence of water borne diseases. Boiling and the use of disinfectants such as chlorine may be recommended for treatment before the water from the springs is consumed. In the absence of chlorine, natural water purifier like Moringa oleifera may be used. Treatment using Moringa oleifera could remove 90 - $99 \%$ of bacteria contained in the spring's water. However, the use of chemicals such as aluminium sulphate and chlorine may be pose health dangers to people if present in treated water at high concentration. Apart from this, chemical treatments are expensive (Fuglie, 1999). 
Hydrochemical Characteristics of Springs.....

\section{REFERENCES}

Aniah, EJ, Eja, EI, Otu, JE, Ushie, MA (2009).

Patronage of ecotourism potential as a strategy for sustainable tourism development in Cross River state, Nigeria. J. Geography and Geology 1 (2): 20-27.

APHA Standard methods for the examination of water and wastewater (1989). $17^{\text {th }}$ ed. American Public Health Association, American Water Works Association and Water Pollution Control Federation, Washington, DC. Pp. 49.

Bruvold, W.H. and Ongerth, H. J. 1969. Taste quality of mineralized water. Journal of the American Water Works Association, 61: 170.

CEC (Commission of European Communities) (1988). European community environmental legislation: 1967-1987. Document Number XI/989/87. Directorate-General for Environment Consumer Protection and Nuclear Safety. Brussels, Belgium. 229 pp.

Department of National Health and Welfare (Canada) (1978). Guidelines for Canadian

drinking water quality. Supporting documentation. Ottawa.

Edberg, SC; Allen, MJ; Smith, DB (1988). National field evaluation of a defined substrate method for the simultaneous enumeration of total coliforms and Escherichia coli from drinking water: comparison with the standard multiple tube fermentation method. Appl. Environ. Microbiol. 54(1):595-601.

Edberg, SC; Patterson, JE; Smith, DB (1994). Differentiation of distribution systems, source water, and clinical coliforms by DNA analysis. J. Clin. Microbiol. 32:139-42.

Environment Canada (1977). Surface water quality in Canada - an overview. Water Quality Branch, Inland Waters Directorate.

EPA (2006). Water Quality Criteria Fact Sheet. United States Environmental Protection Agency, Washington DC.

Fuglie, LJ (1999). The miracle tree, Moringa oleifera: Natural : Nutrition for the Tropics Church World Service, Dakar, Senegal. Pp. 63.
King, M (2008). Bottled Water - Global Industry Guide - New Research Report on Companies and Markets. No.688919.

Lamoreaux, PE; Tanner, JT (2001). Springs and bottled waters of the world (eds.)Ancient History, Source, Occurrence, Quality and Use. New York. Springer-Verlag

Mento d I'exploitant de leau et del I'assainissesment (1980). Lyonnaise Deseaux, p. 273-283.

Nkono, NA; Asubiojo, OI (1998). Elemental composition of drinking water quality in three States in South-Eastern Nigeria. J. Radioanal. Nuclear Chem. 227(1-2): 117-119.

Nordberg, GF; Goyer, RA; Clarkson, TW (1985). Impact of effects of acid precipitation on toxicity of metals. Environ. Health Perspect. 68:169-180.

Odigi, MI, Ezepue, MC, Onyeagocha, AC (1993). Geochemical evolution of Pan-African magmatic rocks from the basement complex between Okene and Lokoja, Southwestern Nigeria. J. African Earth Sciences (and the Middle East). Volume 17 (4): 415579.

Orebiyi, EO; Awomeso, AJ; Martins, O; Idowu, AO; Oguntoke, O; Taiwo, AM (2010) Assessment of Pollution Hazards of Shallow Well Water in Abeokuta and Environs. Am. J. Environ. Sc.. 6 (1): 50-56.

Stelma, GN (Jr.); McCabe, LJ (1992). Non point pollution from animal sources shellfish sanitation. Journal of food Protection 55(8):649-656.

USEPA (2002). National Standards for Drinking Water. EPA 816-F-02-013.

WHO, 2008. World Health Organization, Guidelines for drinking water quality, $3^{\text {rd }} \mathrm{Ed}$. Incorporating the first and second addenda. Vol. 1 Recommendation, Geneva

Zhou, X., Li, R., Zhang, H. and Zhang, L., 2006. Characteristics of natural low $\mathrm{pH}$ groundwater in the coastal aquifers near Beihai, China. Chinese J. Geochemistry, 25 (1):228. 